\title{
Study on the Influence of Stray current Between Sacrificial Anode Cathodic Protection and Impressed Current Cathodic Protection in Marine Environment
}

\author{
Jin-A Jeong ${ }^{\dagger}$ and Ki-Joon Kim \\ Korea Maritime University, 1, Dongsam-dong, Youngdo-ku, Busan city, 606-791, Korea \\ (Received April 23, 2012; Revised June 27, 2012; Accepted June 27, 2012)
}

\begin{abstract}
Cathodic protection $(\mathrm{CP})$ is widely used as a means of protecting corrosion for not only marine structures like ship hulls and offshore drilling facilities, but also underground structures like buried pipelines and oil storage tanks. The principle of CP is that the anodic dissolution of metal can be protected by supplying electrons to the cathode metal. When unprotected structures are nearby to CP systems, interference problems between unprotected and protected structures may be happened. The stray current interference can accelerate the corrosion of nearby structures. So far many efforts have been made to reduce the interference in the electric railway systems adjacent to the underground metal structures like buried pipelines and gas/oil tanks. During recent few decades the protection technologies against stray current induced corrosion have been significantly improved and a number of techniques have been developed. However, there is very limited information an marine environments. Some complex harbor structures are protected by two cathodic protection systems, i.e. sacrificial anode cathodic protection(SACP) and impressed current cathodic protection(ICCP). In this case, when the protection current from sacrificial anodes returns to the cathode through electrolyte, it passes through nearby other low resistance metal structures. In many cases the stray current of ICCP systems influences the function of SACP. In this study, the risk of stray current from the SACP system to adjacent reinforced concrete structures has been verified through laboratory experiments. Concrete and steel pile structures modeled a part of bridge have been investigated in terms of CP potential and current between the two. The variation of stray current according to the magnitude of ICCP/SACP has been studied to mitigate it and to suggest the proper protection criteria.
\end{abstract}

Keywords : cathodic protection, ICCP, SACP, stray current, interference

\section{Introduction}

It is well recognized that large harbor structures in ports suffer the corrosion damage due to chlorides in marine environment. The harbor structures are made of concrete or steel materials, and the upper slabs and beams of pier are generally made of reinforced concrete and the lower parts made of reinforced concrete or steel piles to support the upper parts.

To protect the corrosion damage in marine environment, cathodic protection $(\mathrm{CP})$ has been used for decades and now it becomes a proven technology to protect the harbor structures successfully. ${ }^{1)}$ Impressed current cathodic protection(ICCP) and sacrificial anode cathodic protection (SACP) are selected according to structural, environmental and/or economical conditions. SACP is mainly used in

\footnotetext{
${ }^{\dagger}$ Corresponding author: jina@hhu.ac.kr
}

steel structures which are relatively simple for installation and easy for maintenance. ICCP is mostly used in concrete structures which need a high current density to protect through a concrete with high resistivity. ${ }^{2)}$

These days harbor structures are becoming larger and more complex because of increasing trading and shipping world-widely. To protect these large and complex structures including concrete slabs/piles and/or steel piles, more complicated CP systems like both ICCP and SACP may be needed. In these cases the interference between both systems occur and the corrosion problems due to stray current may be anticipated. An over-protection current from ICCP system or a significant increase of sacrificial anode consumption is possible due to interference problems.

In the underground facilities like subway railroads and gas pipelines, the protection technology to mitigate the stray current have been significantly developed during the 
last three decades, ${ }^{3), 4}$ however, there is little information regarding the interference behavior in harbor structures, especially the complex ICCP and SACP systems.

The purpose of this study, therefore, is to reveal the stray current problems occurred between a concrete structure with ICCP system and a steel pile structure with $\mathrm{SACP}$ one. In addition the proper protection conditions have been studied to minimize the stray current corrosion in those complex structures.

\section{Experimental methods}

Fig. 1 shows the experimental equipments to test the stray current between concrete and steel structures in this study. Two carbon steel pipes with $65 \mathrm{~mm}$ in diameter and $68 \mathrm{~cm}$ in length have been used as a steel structure, and two reinforcing bars(rebar) of $\mathrm{D} 19^{5}$ ) are installed in each upper and lower concrete slabs and piles $(35 \mathrm{~cm} \times 8$ $\mathrm{cm} \times 10 \mathrm{~cm}$ ). The size of concrete structure was $40 \mathrm{~cm}$ in horizontal length and $68 \mathrm{~cm}$ in height with a shape of bridge section. The mixed design of concrete mortar in specimens was 1:2:0.5 (Cement:Sand:Water), and all tests were carried out in natural seawater.

For a cathodic protection(CP), two Zn bulk anodes(1 $\mathrm{cm} \times 1 \mathrm{~cm} \times 30 \mathrm{~cm}$ ) were installed with steel pile specimen for SACP system, ${ }^{6,7)}$ and Ti-ribbon $(2 \mathrm{~cm} \times 16 \mathrm{~cm} \times 0.5 \mathrm{~mm})$ anodes in concrete specimen was used as an insoluble anode for ICCP system. ${ }^{8)}$ All electric connections among rebar, piles and anodes in the test system have been checked after installing them in seawater bath which has the water level of up to $35 \sim 40 \mathrm{~cm}$ height.

There are two dominant test systems in this study, i. e. the first is SACP dominant and the second ICCP dominant. In order to figure out the interference phenomena between ICCP and SACP, the stray current has been measured between them, and the potential change by a power supplier has been compared to control the amount of stray current. For the investigation of electrochemical characteristics, corrosion and protection potentials, CP currents, 4-hour depolarization potentials have been measured in this study. High impedance multi-meter and silver-silver chloride electrodes (SSCE) have been used for the measurement of potentials of corrosion/protection and 4-hour decay, and $10 \mathrm{ohm}$ resistor has been utilized to measure the both CP and stray currents between specimens. Multichannel power unit (model:CR-1212) has been used to supply ICCP power, and the measured data including CP potentials and currents were automatically stored in the data acquisition units with computer.

\section{Results \& discussion}

Fig. 2 and 3 present the protection effect by sacrificial anode CP for steel pile structures. When $\mathrm{Zn}$ sacrificial anodes were connected to the steel pile, the initial potential was dramatically decreased to $-980 \sim-1020 \mathrm{mV} / \mathrm{SSCE}$ since the cathodic polarization occurs on the surface of steel (cathode). It was thought that the difference of CP potential between No.1 \& No.2 steel piles was the half cell potential difference of used anodes individually. The initial current was about $90 \mathrm{~mA}$ which was relatively large, however, it was reduced to less than $10 \mathrm{~mA}$ within hours of $\mathrm{CP}$, which is the typical trend of general potential and current variation in cathodic protection, due to the formation of calcareous deposits in natural seawater.

The interference problem between the concrete pile

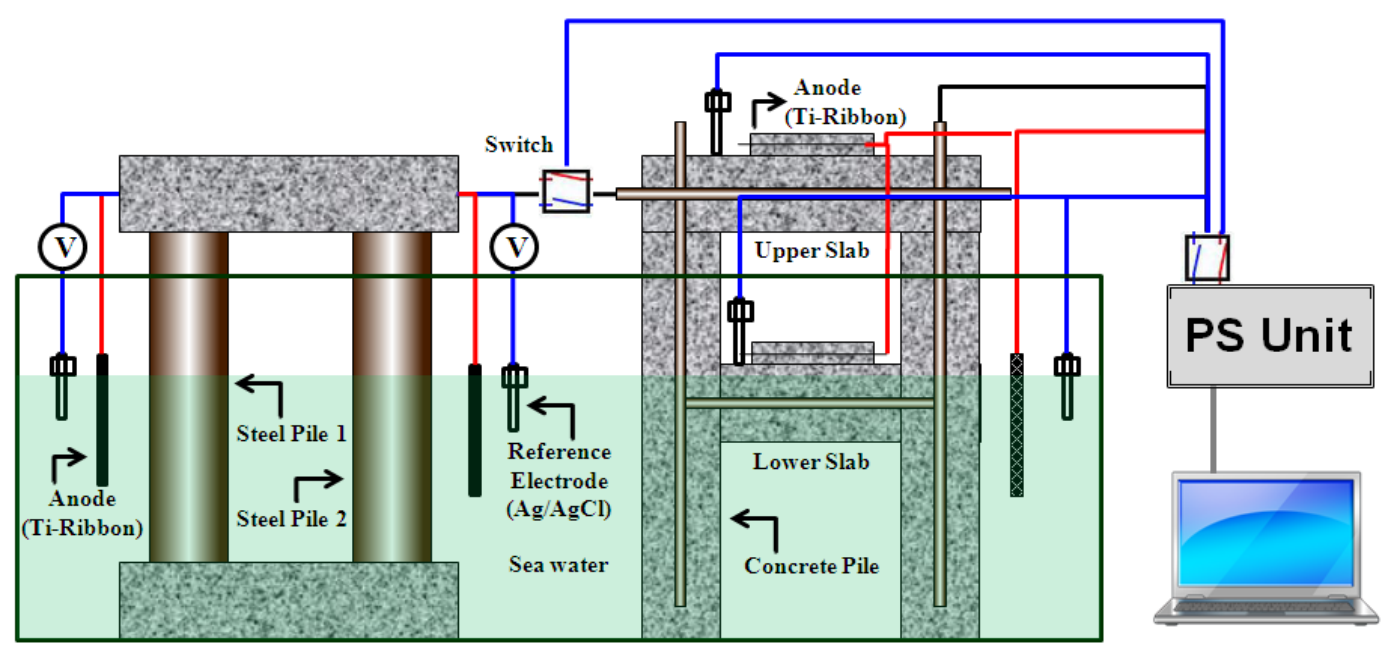

Fig. 1. Experimental Set-up. 
specimen applying ICCP and the steel pile one with SACP has been studied for about a month period in natural seawater. Table 1 2 represent the experimental results of comparison between the connection and disconnection of two structures. When the two structures are disconnected, the steel pile showed $-984 \mathrm{mV} / \mathrm{SSCE}$ and $-1,011 \mathrm{mV}$ of enough $\mathrm{CP}$ potential, $262 \mathrm{mV}$ and $263 \mathrm{mV}$ of good 4-hour decay potential, and $4 \mathrm{~mA}$ and $5 \mathrm{~mA}$ of sufficient $\mathrm{CP}$ current. In the case of concrete specimen the setting potential for $\mathrm{CP}$ was $-850 \mathrm{mV} / \mathrm{SSCE}$ at the underwater zone of concrete pile. Therefore, the total CP current to maintain the setting potential was $2.6 \mathrm{~mA}$. At this point, the protection potential of upper slab was $-378 \mathrm{mV}$, and the lower slab $-775 \mathrm{mV}$. The 4-hour decay potentials were $76 \mathrm{mV}$ at the upper slab, $201 \mathrm{mV}$ at the lower slab and $258 \mathrm{mV}$ at the underwater concrete piles. The 4hour-decay value at the upper slab did not reach to $100 \mathrm{mV}$ of CP criteria in ASTM standard, ${ }^{9), 10)}$ since the part of slab has been exposed to and dried in laboratory atmosphere all the time, and the resistivity was thought to be too high to flow the protection current.

When the two(steel and concrete piles) structures were electrically connected, the protection characteristics have changed due to the interference between the ICCP and the SACP systems. In the steel pile specimens with SACP, the protection potentials have been increased about $6 \sim 7$ $\mathrm{mV}$, the 4-hour decay potential $41 \sim 43 \mathrm{mV}$, and the protection current $3 \mathrm{~mA}$, respectively. In the concrete pile specimens with ICCP, the potential of underwater part of concrete was $-972 \mathrm{mV} / \mathrm{SSCE}$ which was far below from

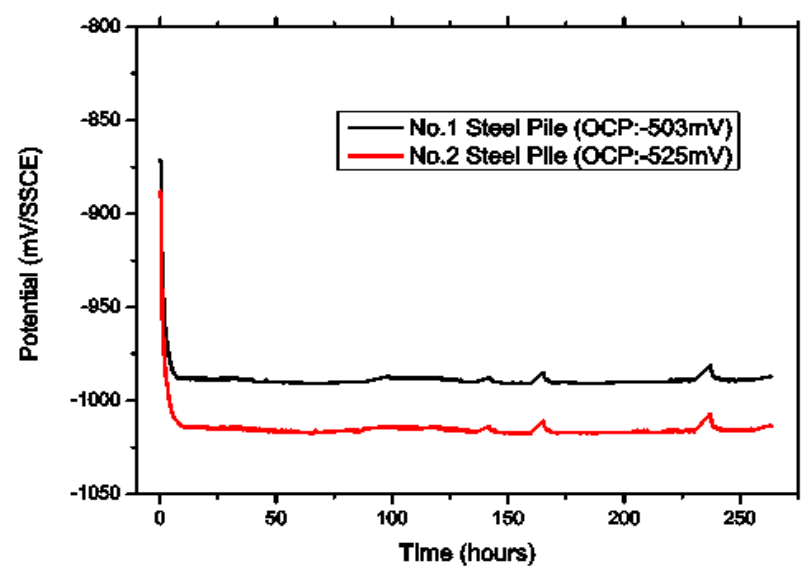

Fig. 2. CP potential variation of steel pile specimens.

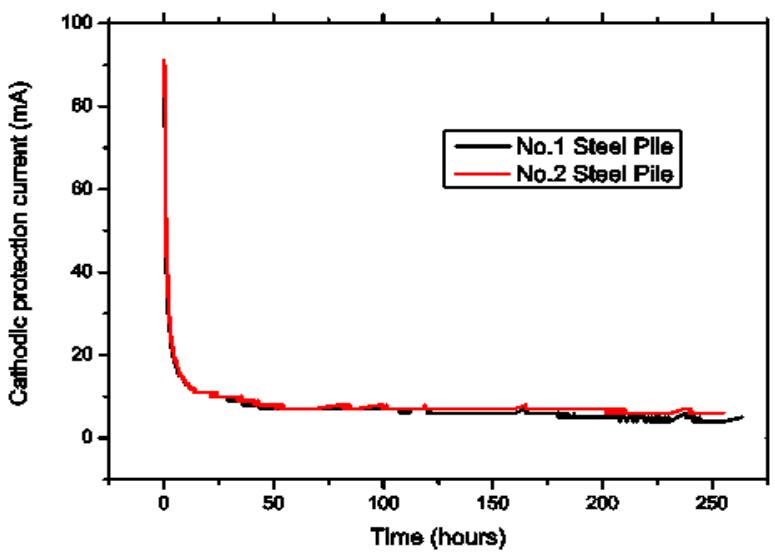

Fig. 3. CP current variation of steel pile specimens.

Table 1. Protection data for CP when steel and reinforced concrete structures were disconnected. (Setting potential:-850 mV/SSCE)

\begin{tabular}{lccccc}
\hline \multicolumn{1}{c}{ Specimen type (CP type) } & \multicolumn{2}{c}{ Steel pile specimen (SACP) } & \multicolumn{2}{c}{ Concrete pile specimen (ICCP) } \\
\hline \multicolumn{1}{c}{ Location } & Steel pile1 & Steel pile2 & Upper slab & Lower slab & Concrete pile \\
\hline CP potential & $-984 \mathrm{mV}$ & $-1011 \mathrm{mV}$ & $-378 \mathrm{mV}$ & $-775 \mathrm{mV}$ & $-851 \mathrm{mV}$ \\
\hline 4H decay potential & $262 \mathrm{mV}$ & $263 \mathrm{mV}$ & $76 \mathrm{mV}$ & $201 \mathrm{mV}$ & $258 \mathrm{mV}$ \\
\hline CP current & $4 \mathrm{~mA}$ & $5 \mathrm{~mA}$ & & $2.6 \mathrm{~mA}$ \\
\hline Stray current & \multicolumn{2}{c}{$0 \mathrm{~mA}$} & $0 \mathrm{~mA}$ \\
\hline
\end{tabular}

Table 2. Protection data for CP when steel and reinforced concrete structures were connected. (Setting potential:-850 mV/SSCE)

\begin{tabular}{lccccc}
\hline \multicolumn{1}{c}{ Specimen type (CP type) } & \multicolumn{2}{c}{ Steel pile specimen (SACP) } & \multicolumn{2}{c}{ Concrete pile specimen (ICCP) } \\
\hline \multicolumn{1}{c}{ Location } & Steel pile1 & Steel pile2 & Upper slab & Lower slab & Concrete pile \\
\hline CP potential & $-977 \mathrm{mV}$ & $-1005 \mathrm{mV}$ & $-138 \mathrm{mV}$ & $-809 \mathrm{mV}$ & $-972 \mathrm{mV}$ \\
\hline 4H decay potential & $305 \mathrm{mV}$ & $304 \mathrm{mV}$ & $0 \mathrm{mV}$ & $171 \mathrm{mV}$ & $291 \mathrm{mV}$ \\
\hline CP current & $7 \mathrm{~mA}$ & $8 \mathrm{~mA}$ & & $0 \mathrm{~mA}$ \\
\hline Stray current & \multicolumn{2}{c}{$7 \mathrm{~mA}$} & $0 \mathrm{~mA}$ \\
\hline
\end{tabular}


the setting potential, $-850 \mathrm{mV}$. Stray current from SACP anode flow to the underwater part of concrete, therefore $\mathrm{CP}$ potential of lower slab and concrete pile in Table 2 . are more negative than $\mathrm{CP}$ potential of Table 1 . In the upper slab it was $-138 \mathrm{mV}$ which was increased $240 \mathrm{mV}$ from the potential before the connection, however, the lower slab was $-809 \mathrm{mV}$ which was decreased $34 \mathrm{mV}$ from before. The potential of underwater part was continued below the setting potential $(-850 \mathrm{mV})$, and the protection current was fallen down to $0 \mathrm{~mA}$, since some protection current came from $\mathrm{Zn}$ anodes installed to protect the steel pile. It was confirmed by the current measurement between the two structures, and the leakage current was about $7 \mathrm{~mA}$. Due to the fall-down of output current from ICCP system to $0 \mathrm{~mA}$, the potential of upper slab which was exposed to atmosphere was decreased nearly up to the potential before applying cathodic protection. It was found that there is a possibility that some part can be an under or no protection at this overlapped area between ICCP and SACP.

Fig. 4 is the 4-hour decay potentials at each location in both specimens in the condition of three different set-potentials to mitigate the under protection problem between SACP and ICCP systems. At $-850 \mathrm{mV} / \mathrm{SSCE}$ of setting potential, the decay potential of upper slab was $0 \mathrm{mV}$, since the stray current from $\mathrm{Zn}$ anode influenced the ICCP system in concrete specimen. At $-1,000 \mathrm{mV} / \mathrm{SSCE}$ of setting potential, the decay potential of steel pile became 40 $\mathrm{mV}$ lower than the decay potential at $-850 \mathrm{mV} / \mathrm{SSCE}$ of setting potential, since the protection potential of $\mathrm{Zn}$ anode did not influence on the concrete specimen. However, those of upper and lower slabs were about $80 \mathrm{mV}$ and $50 \mathrm{mV}$ higher, respectively.

The under-water area of concrete pile showed only 10

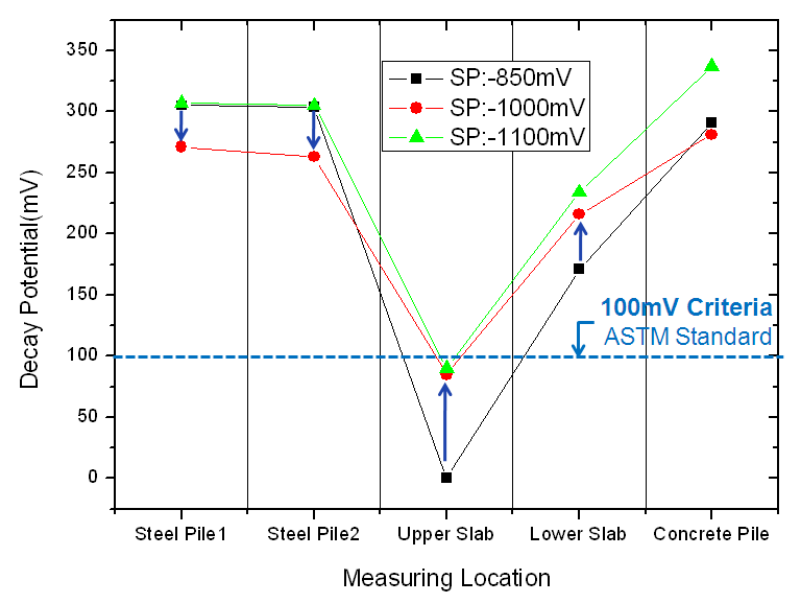

Fig. 4. Decay potentials at each location with the setting CP potential in ICCP system.

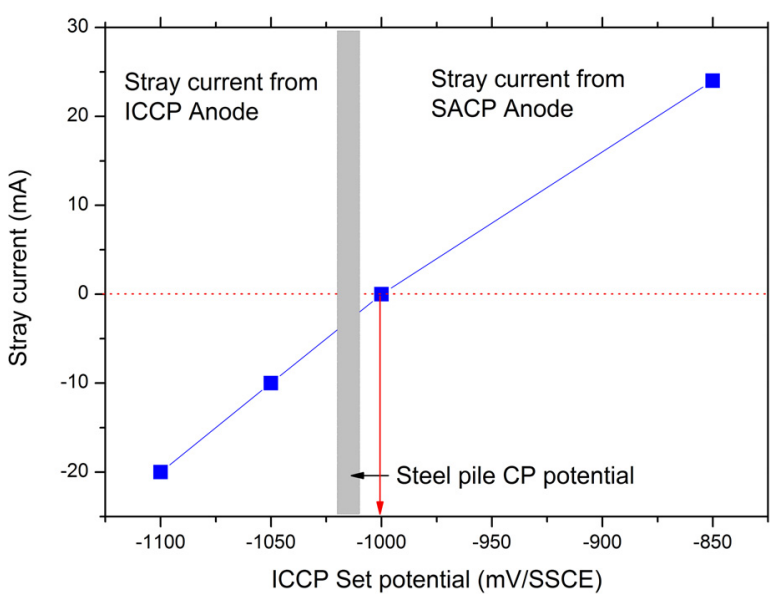

Fig. 5. Variation of stray current with setting potential at ICCP system.

$\mathrm{mV}$ decay potential. This means that $-1,000 \mathrm{mV}$ of setting potential supplied enough protection current even to the upper slab, and both specimens became a good protection state to minimize under-protection area. When potential of ICCP was set $-1,100 \mathrm{mV} / \mathrm{SSCE}$, the decay potential of steel pile became about $40 \mathrm{mV}$ higher than the decay potential at $-850 \mathrm{mV} / \mathrm{SSCE}$, and that of concrete pile was somewhat increased as well.

Fig. 5 is the results of stray current measured by ammeter between steel and concrete pile specimens. The stray current values were varied according to the setting potentials as indicated in Fig. 4. At higher than $-1,000 \mathrm{mV} /$ SSCE of setting potential in underwater concrete with ICCP system, the direction of stray current was from steel pile(SACP) to concrete(ICCP). The lower the setting potential made, the more the stray current formed. The increment of stray current with the variation of setting potential was a linear trend as shown in Fig. 5. The optimum CP potential to prevent the stray current between ICCP(in concrete) and SACP(in steel piles) was $-1000 \mathrm{mV} / \mathrm{SSCE}$, 10 20 $\mathrm{mV}$ higher than potential as marked by a vertical band in Fig. 5. So-called the gab potential between two structures may be varied according to the structure size, the distance between structures, concrete resistivity, and some environmental factors. More experiments may be needed to establish the optimum potential to minimize the stray current in this kind of complex CP system.

\section{Conclusions}

When ICCP and SACP are properly designed and electrically insulated(separated), both CP systems will work correctly and satisfy the CP criteria of ASTM standard in general. When the two systems, however, are electri- 
cally connected, stray current will be formed in one side of the system depending upon structure size, shape and environments. Both to minimize the stray current and to optimize the cathodic protection in a system, the electrochemical measurement and the adjustment of $\mathrm{CP}$ setting potential in ICCP system will be needed.

\section{References}

1. J. E. McCoy, Trans. Inst. Mar. Eng., 82, 210 (1970).

2. G. Jones, I. Wood, and P. Lambert, Concr. Eng. Int., 3, 66 (1999).
3. C. O. Jung and H. H. Choi, KIGAS, 12 (2008).

4. Y. S. Kim, S. J. Park, D. Hwangbo, and M. C. Shin, Corros. Sci. Tech., 11, 26 (2012).

5. KS D3504, 7 (1963).

6. C. Rousseau, F. Baraud, L. Leleyter, and O. Gil, Journal of Hazardous Materials, 167, 953 (2009).

7. W. Chu and W. Hartt, NACE International, 7287 (2007).

8. J. P. Broomfield, Corrosion of Steel in Concrete, E \& FN Spon, 120 (1997).

9. ASTM C876-91, Annual Book of ASTM Standards, 03.02 (1994).

10. NACE Standard, RP0290, NACE International (2000). 